\title{
Squamous Cell Carcinoma of the Penis, Usual Type
}

National Cancer Institute

\section{Source}

National Cancer Institute. Squamous Cell Carcinoma of the Penis, Usual Type. NCI

Thesaurus. Code C6979.

A squamous cell carcinoma that arises from the penis and cannot be classified according to other morphologic subtypes. 